\title{
Issues of New Constitution Making in Sri Lanka: Towards Ethnic Reconciliation by Laksiri Fernando (Charleston, SC: 2016, 189 pages)
}

\author{
Reviewed by Kalinga Tudor Silva* \\ Emeritus Professor in Sociology, University of Peradeniya, Peradeniya, Sri Lanka.
}

This is a critical assessment of the constitution making process in Sri Lanka with a focus on and a critical engagement with the need for ethnic reconciliation through constitutional reform as the overall theme of the publication. The volume contains as assortment of papers some of which had been previously published as journal or newspaper articles. According to the author,

"( $t$ )he timing of this publication is the ongoing efforts in Parliament in consultation with the public and various stakeholders in drafting a new constitution and adopting it in Parliament subsequently endorsed by a referendum, according to constitutional provisions in the present constitution (1978)" (p. vii).

This can be seen as a timely contribution to an important political discourse in the country by one of Sri Lanka's leading political scientists currently living in Australia but a frequent commentator on politics and social issues in Sri Lanka.

The book provides an excellent overview of the background to the current constitution making process in Sri Lanka. The book is divided into three parts. Part One, titled "General Concerns of Constitution Making", analyses conceptual and philosophical issues in constitution making process, also drawing from the experiences of other countries. Further, it addresses the question why a new constitution is necessary as remedy for current problems in the country. Part Two describes the constitutional proposals Laksiri Fernando has presented to the Public Representation Committee (PRC), appointed by the government, formed in 2015 to solicit public opinions and suggestions regarding the next constitution. Part Three, examines critically the ongoing constitution making process. In exploring why a constitutional reform is necessary at the present juncture, the book examines the political crises in recent years, increased centralisation of power and the country's poor record in human rights, particularly after the constitutional change in 1978, continuation of ethnic polarization in the country since the end of war and the demand for constitutional reform by civil society, ethnic minorities and other key stakeholders in society, while also recognising the diverse and often contradictory reasons why different sections of society want to go for a new constitution.

The book launches a scathing attack on the 1978 constitution of Sri Lanka and the presidential system of government it established for its centralising tendencies and the unprecedented concentration of power in the hands of an elected president. In justifying the presidential system, J. R. Jayewardene noted,

"Such an executive is a strong executive seated in power for a fixed number of years, not subject to the whims and fancies of an elected legislature; not afraid to take correct but unpopular decisions because of censure from its parliamentary party". (page 31: emphasis Fernando).

According to Fernando, J. R. Jayawardene wanted to abolish the electorates and,

"that abolition eventually spelled disaster to the democratic system that the people were accustomed since 1931. More precisely, he wanted to unplug the legislators from the voter base.." (page 30). 
Referring to the proportional representation (PR) system under the 1978 constitution, Fernando stated,

"The PR system introduced under the 1978 constitution with preferential voting for party candidates on the district basis, in fact produced a breed of legislators who were neither responsible for the voters nor even to the political parties" (page 30).

This is indeed a valid observation considering the phenomenon of party crossovers that became a regular feature following subsequent elections.

The book also highlights the majoritarian tendencies reinforced by the 1978 constitution as a potential trigger for increased Tamil militancy culminated in the rise of Tamil separatist movement and its armed struggle. The elevated position of Buddhism and Sinhala language in the constitution obviously date back to the previous constitution (1972), but perhaps what is new is the possibility of an executive president to legitimise his/her power and resort to oppression of minorities deploying these majoritarian provisions. What the book does not explore, however, is the capacity of minority voters to influence the election of a president and parliamentarians under the PR system. For instance, the 2015 presidential election,was a clear instance where the minority vote actually played a significant role in electing Maithripla Sirisena over Mahinda Rajapaksa. While it is true that the 1978 constitution was deployed by the state to counter and oppress anti-state agitators whether they came from JVP or LTTE, it is questionable to attribute the failure of the Sri Lankan state in terms of accommodating minority interests to the 1978 constitution alone. It can only be seen as a particular moment in a gradual deterioration of ethnic relations in the country from pre-independence era with 1956, 1983 and 2006 to 2009 as important turning points in this longer historical process.

In the final analysis, the book places a lot of emphasis on devolution of power as an important strategy for post-war ethnic reconciliation in the country. The $13^{\text {th }}$ Amendment to the Constitution introduced under the Indo Lanka Accord in 1987 is seen as an important breakthrough from the angle of moving away from the concentration of power in the centre resulting from the 1978 constitution. The book claims that,

"The devolution or Provincial Council system introduced in 1987 could be considered the most welcome development in the country since independence, giving some room for horizontal spread of democracy, although the sysem has not yet taken much root. The acid test of democracy in the coming future will be whether this system would be extended or abolished or modified to make it more effective or ineffective" ( page 21).

According to Fernando, while the system of Provincial Councils marks a good beginning towards ethnic reconciliation, it is perhaps not a sufficient condition given the complexity of issues in post-war Sri Lanka. He identifies four areas where improvements can be made in order to further advance ethnic reconciliation. They include (1) reducing the concurrent list (for instance, education must be a devolved subject rather than a concurrent one) (2) eliminating ambiguities between the national list and the provincial list (3) giving more power to provincial councils and Pradeshiya Saba for development work and (4) creating a framework for making sufficient fiscal and administrative resources available to the provinces. He proposes that there should be cooperative devolution whereby cooperative action between centre and periphery and between two or more Provincial Councils must be promoted in ways that are mutually beneficial. He does not think that $13+$ will be a step towards separation if it is pursued in the correct way. The author's specific proposals in this regard are presented in Part Two of the book.

The final chapter begins with a reference to a student clash between Tamil and Sinhala students in the Jaffna University in July, 2016. This incident illustrates the absence of what the author identifies as bridging social capital that connects people of different communities, even in state educational institutions, where students follow the same courses and theoretically interact with each other on a daily basis. The fact that student clashes erupted along ethnic lines indicate that ethnic reconciliation has not occurred in spite of the end of war, law and order situation has been restored and people go about their life as if things are normal. Commenting on this situation, one observer from Jaffna reportedly ask,

"can any authorities explain why except in one or two faculties Tamil-Sinhala students do not even smile at each other even when they walk past each other" (page 177).

In many ways this sums up the nature of ethnic relations in war affected areas in Sri Lanka.

In a section titled "Social and Ethnic Harmony", in his proposals submitted to Public Representation Committee (PRC), Fernando made the following submissions:

"The State shall not promote in any manner ethnonationalism in the country directly or indirectly. 
On the contrary, the State shall promote civic nationalism liberal patriotism based on most enlightened religious and secular principles, fundamental human rights and cosmopolitanism. The State shall launch educational programs, formal and informal, to promote the above. All political parties, non-government sectors and all citizens are obliged to do the same and participate in such educational programs at will while retaining the freedom to peacefully differ, criticize and seek changes to the policies and practices of the State in respect of the above" (page 103).

These are certainly important issues that should receive the attention of constitution makers and citizens in general.

In spite of its significant contribution to an ongoing national debate, as an academic publication the book has certain notable weaknesses. The discreet articles have not been properly edited when included in the current volume. The chapters are self-identified as "this essay" (page 4) or "this article" (page 5) in spite of their inclusion as chapters in the book format. More importantly some of the demographic data presented are outdated. For instance, the ethnic and religion-wise population data presented in Table 2 (page 14) use population data from 1946 and 1981 censuses. Considering the war induced population exodus affecting the Tamil minority in particular the validity of this data for political analysis of current developments is questionable. In a similar vein, the book states in page 20 that the election to the Northern Provincial Council is yet to be held.

These oversights aside, this volume makes a valuable contribution to the ongoing constitutional debates in Sri Lanka. Particularly at a time when public support for devolution seems to be dwindling on various ethnic fronts, the book stresses the point that from the angle of ethnic reconciliation we have no option but to make devolution work and make it acceptable to all parties concerned. 